\title{
Comparing two frailty concepts among older people with intellectual disabilities
}

\author{
Josje D. Schoufour ${ }^{1,2} \cdot$ Michael A. Echteld ${ }^{1} \cdot$ Heleen M. Evenhuis ${ }^{1}$
}

Published online: 24 June 2016

(C) The Author(s) 2016. This article is published with open access at Springerlink.com

\begin{abstract}
In general, disabilities are considered a consequence of frailty rather than a cause of frailty, whereas in people with intellectual disabilities (ID), disabilities are often lifelong, which could have consequences for the feasibility and validity of frailty instruments. To better understand frailty in people with ID, we compared two broadly used concepts: the frailty phenotype (FP) and the frailty index (FI) taking into account their feasibility (e.g., percentage of participants able to complete the frailty assessments), agreement, validity (based on 5-year mortality risk), influence of motor disability, and the relation between single frailty variables and mortality. The FI and an adapted version of the FP were applied to a representative dataset of 1050 people with ID, aged 50 years and over. The FI was feasible in a larger part of the dataset (94\%) than the adapted FP: $29 \%$ for all five items, and $81 \%$ for at least three items. There was a slight agreement between the approaches $(\kappa=0.3)$. However defined, frailty was related with mortality, but the FI showed higher discriminative ability and a stronger relation with mortality, especially when adjusted for motor disabilities. Concluding, these results imply that the used FI is a stronger predictor for mortality and has higher feasibility than our adaptation of the FP, in older people with ID. Possible explanations of our findings are that we did not use the
\end{abstract}

Responsible editor: D. J. H. Deeg.

Josje D. Schoufour

j.schoufour@erasmusmc.nl

1 Intellectual Disability Medicine, Department of General Practice, Erasmus Medical Center, PO box 2040, 3000 CA Rotterdam, The Netherlands

2 Department of Epidemiology, Erasmus Medical Center, PO box 2040, 3000 CA Rotterdam, The Netherlands exact FP variables or that the FI includes multiple health domains, and the variables of the FI have lower sensitivity to lifelong disabilities and are less determined by mobility.

Keywords Frailty · Frailty index · Frailty phenotype . Survival · Intellectual disability

\section{Introduction}

Frailty is a complex cascade that involves several age-related physiological alterations, eventually leading to loss of function and failure to respond to a stressor event (Clegg et al. 2013). The frailty 'phenotype' by Fried et al. (2001), and the frailty index (FI) developed by Rockwood and Mitnitski (Mitnitski et al. 2001; Rockwood and Mitnitski 2007) are the most evaluated and most frequently used measures, representing two different concepts and definitions of frailty (Bouillon et al. 2013).

The frailty phenotype was operationalized as a biological syndrome, based on a cluster of symptoms that are commonly observed in frail older people including unintended weight loss, low grip strength, exhaustion, slow gait speed, and low physical activity (Fried et al. 2001). The underlying concept is the cycle of frailty, based on agerelated physiological changes, including low energy expenditure, nutritional deficiencies, and sarcopenia. Because the frailty phenotype has a clear underlying etiology, it is, although correlated to, distinct from disabilities and chronic disease (Fried et al. 2004). The frailty phenotype distinguishes between three different frailty states, based on the number of symptoms present in a person. If none of the symptoms are present, a person is classified as non-frail, one or two marks a person as pre-frail, and frailty is defined as the presence of three or more. The frailty 
phenotype can relatively easily be used as a clinical assessment for frailty, using clearly described cut-off values.

The FI operationalizes frailty quantitatively as an aspecific accumulation of health deficits in multiple domains, and can include health variables such as signs, diseases, disabilities, laboratory abnormalities, and symptoms as long as they are not too common or too rare, generally increase with age, and together cover several health domains. In order to find an FI that best captures the risk for adverse health outcomes, it has been suggested to also include disabilities and diseases (Theou et al. 2012). The FI-score is a continuous value between 0 and 1 . Because of the continuous nature of the FI, it is possible to study individual changes over time, as frailty is usually an irregular trajectory influenced by stress and recovery (Mitnitski et al. 2012). On the other hand, on a population level, the FI shows very regular characteristics including an exponential relation with age (Mitnitski et al. 2013).

The two approaches agree that, as a consequence of multisystem deterioration, frailty is an age-related state of vulnerability to adverse health outcomes (Theou and Rockwood 2015). Nevertheless, because of different underlying conceptualizations and operationalizations, it has been suggested not to compare the two instruments but rather consider them as complementary to one other (Cesari et al. 2014). Even so, to better understand frailty in populations with different characteristics, it can be helpful to compare different concepts. Previous comparisons showed that the FI has a somewhat stronger relation with negative health outcomes than the phenotype approach (Theou and Rockwood 2015).

In people with intellectual disabilities (ID), insights into how frailty originates, develops, and affects health outcomes are currently speculative. Results from the general population cannot directly be applied to this group, because of their lifelong disabilities (cognitive, motor, and sensory) and chronic comorbidity, which may influence both the development and the consequences of frailty. Moreover, muscle function and mobility play a central role in the frailty phenotype, whereas these frailty characteristics could be lifelong in people with ID and highly determine the frailty status (Evenhuis et al. 2013).

A better understanding of the different concepts of frailty in people with ID can help improve the understanding of frailty in people with ID and better understand how people with ID age. Furthermore, it provides insight and direction for a future-screening instrument for frailty in this lifelong disabled population.

The main aim of our study was therefore to compare the feasibility and validity of the frailty phenotype and the frailty index in older adults with ID. First, feasibility was assessed by evaluating the percentage of participants able to complete the frailty assessments. Second, validity was assessed. Because there is no gold standard for frailty, validity is usually based on criterion validity, in this case the relation with adverse health outcomes. We therefore calculated the relation between frailty and 5-year survival. Third, in addition to general feasibility and criterion validity, we were interested in the predictive value of the single items that are part of the frailty phenotype and the FI in order to find risk factors that highly contribute to the mortality risk of people with ID. Last, because lifelong motor disabilities can highly determine the frailty status, we evaluated the influence of motor disability on the frailty status.

\section{Methods}

\section{Study design and participants}

This study was part of the HA-ID study. This study addressed the health of 1050 older people with ID in the Netherlands. Details about the recruitment and selection process have been described elsewhere (Hilgenkamp et al. 2011). Briefly, the study sample consisted of clients, aged 50 years and over, from three Dutch care provider services offering a broad spectrum of care and support to people with ID. All clients aged 50 years and over $(N=2322)$ were invited to participate. Eventually 1050 clients, or their legal representatives, provided informed consent, forming a nearly representative study sample for the Dutch population of older adults (aged 50 and above) with ID who use formal care, albeit with a slight underrepresentation of men, people aged 80 and over, and people living independently. Ethical clearance was provided by the Medical Ethics Committee of the Erasmus Medical Center Rotterdam (MEC 2008-234) and by the ethics committees of the participating care organizations. The study followed the guidelines of the Declaration of Helsinki.

\section{Data collection}

Baseline data were collected between February 2009 and July 2010 within three main themes: (1) physical activity and fitness, (2) nutrition and nutritional state, and (3) mood and anxiety. Within these themes the participants underwent an extensive diagnostic assessment including a physical assessment, a fitness test battery, several questionnaires (regarding, e.g., nutrition, depression, disabilities), and laboratory tests in addition to the collection of health record data. Data on age, gender, and residential status were collected through the care provider services. Level of ID was obtained from the scores determined by psychologists or test assistants from available IQ tests. The 
diagnosis of Down syndrome was retrieved from medical files. Up to March 2015, all-cause mortality data (time of death) were collected through the care organizations.

\section{Frailty measures}

\section{Frailty phenotype}

Previously, an adapted version of the frailty phenotype was applied using the criteria of the Cardiovascular Health Study (Evenhuis et al. 2012; Fried et al. 2001). According to the original criteria, an individual should be classified as frail if at least three of the following five are present: weight loss, weakness, slowness, low physical activity, and poor endurance or exhaustion. Briefly, weight loss was defined as losing more than $3 \mathrm{~kg}$ within 3 months. Weakness was assessed using a handgrip dynamometer. Slowness was assessed using comfortable walking speed, measured as the average of three recordings of the time to complete a distance of $5 \mathrm{~m}$. Participants in a wheelchair and participants unable to perform the walking test due to physical limitations were also classified as having a slow walking speed. Low physical activity was defined as walking fewer than 5000 steps/day measured with pedometers (NL-1000; New Lifestyles, Lees Summit, MO). Participants in a wheelchair and participants unable to perform the test due to physical limitations were also classified as having low physical activity (less than 5000 steps/day). Exhaustion was defined as answering 'moderate problem' or 'severe problem' to the 'lacks energy' item from the Anxiety, Depression, and Mood Scale (Esbensen et al. 2003). Additional information about the used frailty phenotype variables and the originally intended frailty phenotype criteria are provided in Table 5. Individuals with one or two criteria present were classified as pre-frail. Individuals with no criteria present were classified as non-frail or 'robust.' At least three out of five criteria needed to be known before the frailty phenotype could be applied.

\section{Frailty index}

An FI was previously created with 51 baseline items from the HA-ID study (Schoufour et al. 2013). A standardized procedure was followed to develop the FI (Searle et al. 2008): all items were (1) related to health, (2) positively associated with age, (3) frequently but not too often present in the population $(>5 \%,<80 \%)$, and (4) measured in at least $70 \%$ of the participants. Furthermore, the items did not correlate too strongly with each other $(r<0.7)$, and together the items covered a range of health problems (physical, psychological, and social). Deficits included are, for example, mobility, calf circumferences, bathing, falling, listless, grip strength, HDL cholesterol, and knowing which year it is. An overview of all the deficits included in the FI is provided in Table 4. All items were recorded between 1 (presence of the deficit) and 0 (absence of the deficit). The FI-score was calculated as the total number of deficits present as a proportion of those counted (e.g., 12 deficits in a 51-item FI results in an FI of $12 / 51=0.24)$. In the case of missing data, the deficit was removed from both the numerator and the denominator, but at least 30 deficits were required per individual. For the sake of direct comparisons with Fried phenotype, we used several previously identified cut points. Because using cut points for the FI is generally not advised and cut-offs are arbitrary, we applied three different, previously used, cutoffs for the FI. First of all, an FI of less than 0.2 was considered as non-frail or 'robust,' a score between 0.2 and 0.35 as 'pre-frail,' and a score above 0.35 as 'frail' (Kulminski et al. 2008; Rockwood et al. 2007). Second, an FIscore of $\leq 0.08$ was considered non-frail, a score between 0.08 and 0.25 as pre-frail and a score equal to or higher than 0.25 as frail, in accord with prior studies (Rockwood et al. 2007; Rockwood et al. 2004; Song et al. 2010). Third, we classified participants as non-frail if FI $\leq 0.10$, frail if FI $\geq 0.21$, and pre-frail if the score was between 0.10 and 0.21 , identified using stratum specific likelihood ratios (Hoover et al. 2013).

\section{Statistical analysis}

First, baseline characteristics (gender, age, level of ID, presence of Down syndrome), the mean FI-score and the percentage of non-frail, pre-frail, and frail participants were provided as the percentage for categorical variables and the mean (with $S D$ ) for continuous variables. The prevalence of each item of the phenotype was provided. Second, the feasibility of the instruments was analyzed by calculating the percentage of participants able to complete the frailty assessments. A non-response analysis was performed to compare the participants with and without completed data for frailty, using a Pearson Chi-square for categorical data and ANOVA for continuous data. Third, the Cohen's Kappa statistic was used to estimate agreement between the instruments. For this analysis, the categorized FI was compared with the frailty phenotype (e.g., non-frail, pre-frail, frail). Agreement was considered as poor for Kappa values lower than 0.21 , slight for $0.21-0.40$, moderate for $0.41-0.60$, good for $0.61-0.80$, and excellent for values $0.81-1$ (Cohen 1960). Fourth, the ability to predict 5-year all-cause mortality was calculated for both instruments and compared to each other. The hazard ratio's $(H R)$ for mortality were calculated for the frailty phenotype and for the categorized FI in separate Cox regression models. Dummy variables were composed for the pre-frail and frail 
groups to compare their mortality risk with the non-frail group. Additionally, the $p$ for trend was provided. A comparative analysis was performed by including the two frailty instruments in one Cox regression model. This analysis was repeated with an FI that excluded the criteria that were also used for the frailty phenotype. In other words, the deficits' walking speed, grip strength, fatigue, and weight loss were excluded from the FI. All models were adjusted for age (years), level of ID (with dummy variables for moderate and severe/profound), gender and the presence of Down syndrome. A receiver operating characteristics (ROC) curve was constructed and the area under the ROC curve (AUC) was calculated to measure the discriminative ability of the instruments in relation to survival. These calculations were based on the Nearest Neighbor Estimator, which uses time-dependent ROC and AUC, to account for censoring (Heagerty et al. 2000). In order to find the frailty variables that explained most variance in survival time, we calculated the $H R$ for each FI item and for each frailty phenotype item. Additionally, we added all available frailty measures (frailty phenotype and FI) into a forward Cox Regression model. Full case analysis resulted in a small and very selective group. Therefore, for this analysis, we used a multiple imputation procedure using fully conditional specification (Markov chain Monte Carlo method) with a maximum of 100 iterations. In total, we created 10 imputed datasets using all the frailty measures as predictors in addition to the baseline characteristics-Down syndrome, age, gender, and level of ID. Because we used a stepwise entry of the variables, leading to different predictor sets for the various imputation sets, pooling of the results was impossible. We therefore provide the results of the 10th imputation set. Fifth, the influence of motor disability was assessed by including motor disability into a Cox regression model.

For all survival analyses, the data on participants who were lost to follow-up were censored and the proportional Hazards assumption was tested with the scaled Schoenfeld residuals. Statistical analyses were performed using SPSS version 20.0 and $\mathrm{R}$ version 3.0.0. A two-sided $p$ value of $<0.05$ was considered significant.

\section{Results}

\section{Sample characteristics}

The mean age of the study sample $(n=1050)$ was 61.6 $(\mathrm{SD}=8.0)$. Nearly half were female $(n=511,49 \%)$, nearly half had a moderate level of ID ( $n=506,48 \%)$, and $14 \%$ ( $n=149)$ was diagnosed with Down syndrome. According to the frailty phenotype, 230 (27\%) were classified as non-frail, $508(60 \%)$ as pre-frail, and 110
$(13 \%)$ as frail. The mean FI-score was $0.27(\mathrm{SD}=0.13)$. Using the first defined cut-off (non-frail $<0.2$, frail $>0.35$ ), $325(33.1 \%)$ participants were classified as non-frail, 392 as pre-frail $(37.3 \%)$, and 265 as frail $(25.2 \%)$ according to the FI. According to the second used cut-off (non-frail $\leq 0.08$, frail $\geq 0.25), 33(3.4 \%)$ were non-frail, $445(45 \%)$ pre-frail, and $504(51 \%)$ frail. The third applied cut-off (non-frail $\leq 0.10$, frail $\geq 0.21$ ) classified 65 (6.6\%) participants as non-frail, $285(29 \%)$ as pre-frail, and 632 (64\%) as frail.

\section{Feasibility}

Less than a third of the participants ( $n=307,29 \%)$ could complete the full frailty phenotype assessment as intended. $40 \%(n=419)$ had four completed assessments, $12 \%$ $(n=122)$ had three completed assessments, and $19 \%$ $(n=202)$ had less than three completed assessments. By including all participants with at least three known frailty phenotype criteria, the frailty phenotype could be applied to $848(81 \%)$ participants. Table 1 provides an overview of the feasibility of the single frailty phenotype variables. The 202 excluded participants were on average more intellectually disabled $\left(X^{2}=32.8, p<0.001\right)$, and had on average a higher FI-score $(M=0.31, \mathrm{SD}=0.12)$ than those included $([M=0.27, \mathrm{SD}=0.13], t(982)=3.28$, $p=0.001)$. For other baseline characteristics, no significant differences between the included and excluded participants were found. For 167 participants (17.2\%), all 51 included deficits were known. In 68 (6.4\%) participants, there was too much missing data to calculate an FI. There were no significant associations between the number of missing data and the FI-score or between the participants with a known FI-score $(n=982,94 \%)$ and those without, with respect to gender, age, level of ID, and Down syndrome.

\section{Agreement}

For 838 participants, the frailty phenotype and the FI were known. The Cohen's Kappa agreement between the three categorized FIs and the frailty phenotype ranged between 0.10 and 0.30 , corresponding with poor till fair agreement (Table 2). From the three applied FI cut-off values, only the first (non-frail $<0.2$; frail $>0.35$ ) showed a fair agreement with the frailty phenotype (Kappa agreement 0.3 ). The two other applied FI cut-off points showed poor agreement with the frailty phenotype (Kappa agreement 0.10 and 0.11 ). Each frailty phenotype variable was independently of age, level of ID, gender, and Down syndrome significantly associated with the FI (Table 1). 
Table 1 The variables of the frailty phenotype, feasibility, and association with survival and the frailty index

\begin{tabular}{|c|c|c|c|c|}
\hline Association with & Feasible $(\%)$ & Classified as frail for this item $\mathrm{n}(\%)$ & $\begin{array}{l}\text { Mortality } \\
\text { HR }(95 \% \mathrm{CI})^{\mathrm{a}}\end{array}$ & $\begin{array}{l}\text { Frailty index } \\
B(\mathrm{SE})^{\mathrm{a}}\end{array}$ \\
\hline Grip strength & $977(93)$ & $46(4.4)$ & $2.06(1.13-3.74)$ & $0.07(0.06-0.09)$ \\
\hline Weight loss & $725(69)$ & $384(53)$ & $1.93(1.13-3.31)$ & $0.08(0.05-0.11)$ \\
\hline Exhaustion & $975(92)$ & $171(18)$ & $1.95(1.36-2.81)$ & $0.11(0.09-0.13)$ \\
\hline Slow walking speed & $818(78)$ & $271(33)$ & $3.64(2.31-5.75)$ & $0.15(0.14-0.17)$ \\
\hline Physical inactivity & $422(10)$ & $255(60)$ & $5.43(2.07-14.3)$ & $0.14(0.11-0.16)$ \\
\hline
\end{tabular}

${ }^{a} \mathrm{HR}$ and B are adjusted for age, gender, level of ID, and the presence of Down syndrome. The regression coefficient B represents differences in absolute frailty index score (and corresponding $95 \%$ confidence interval)

Table 2 Agreement among the frailty index (using different cut-off values) and the frailty phenotype based on three frailty categories

\begin{tabular}{|c|c|c|c|c|c|c|}
\hline \multirow[t]{2}{*}{$n=838^{\mathrm{a}}$} & & \multicolumn{5}{|c|}{ Frailty phenotype } \\
\hline & & Non-frail & Pre-frail & Frail & Total & Agreement \\
\hline \multirow[t]{4}{*}{ Frailty index } & Non-frail $<0.2$ & 151 & 146 & 2 & 299 & \multirow[t]{4}{*}{0.30} \\
\hline & Pre-frail $0.2-0.35$ & 68 & 232 & 27 & 327 & \\
\hline & Frail $>0.35$ & 5 & 126 & 81 & 212 & \\
\hline & Total & 224 & 504 & 110 & 838 & \\
\hline \multirow[t]{4}{*}{ Frailty index } & Non-frail $\leq 0.08$ & 23 & 5 & 0 & 28 & \multirow[t]{4}{*}{0.10} \\
\hline & Pre-frail $0.08-0.25$ & 162 & 235 & 8 & 405 & \\
\hline & Frail $\geq 0.25$ & 39 & 264 & 102 & 405 & \\
\hline & Total & 224 & 504 & 110 & 838 & \\
\hline \multirow[t]{4}{*}{ Frailty index } & Non-frail $\leq 0.10$ & 45 & 12 & 0 & 57 & \multirow[t]{4}{*}{0.11} \\
\hline & Pre-frail $0.10-0.21$ & 110 & 151 & 2 & 263 & \\
\hline & Frail $\geq 0.21$ & 69 & 341 & 108 & 518 & \\
\hline & Total & 224 & 504 & 110 & 838 & \\
\hline
\end{tabular}

${ }^{a}$ From the total HA-ID population $(n=1050), 838$ had a known frailty phenotype and a frailty index score

\section{Survival}

Of the total HA-ID cohort $(n=1050), 207$ participants died during the follow-up. Table 3 shows the HR's for prefrail and frail individuals, using the non-frail state as a reference group, and the $\mathrm{p}$ for trend across all categories. However defined, frailty was significantly related to mortality. Those classified as pre-frail or frail using the frailty phenotype were, respectively, 2.04 and 4.20 times more likely to die during the follow-up period than those classified as non-frail. Those classified as pre-frail or frail with the FI (using the $<0.2$ to define robust, and $>0.35$ to define frail participants) were, respectively, 2.27 and 10.3 times more likely to die than the non-frail group. If both instruments were included in one Cox regression model, the frailty phenotype no longer predicted mortality, whereas the FI did. If all frailty phenotype items were excluded from the FI, virtually the same results were obtained. Although the HR for the frailty phenotype groups slightly increased, they remained not significant (data not shown). For the two FI scores that used the lowest cut-off of 0.08 or 0.10 , two participants died in the reference group. There was no association with mortality in the pre-frail and frail participants compared to the reference group. The $\mathrm{p}$ for trend was highly significant. Repeating the analysis with all participants with a known FI $(n=982)$ revealed somewhat stronger associations between the FI and mortality (Table 6). The ROC curve showed that the first categorized FI (robust $<0.25$, frail $>0.35$ ) had a higher discriminative ability in relation to all-cause mortality $(\mathrm{AUC}=0.78)$ than the frailty phenotype $(\mathrm{AUC}=0.64$ ). The second (robust $\leq 0.08$, frail $\geq 0.25$ ) and third cut values (robust $\leq 0.10$, frail $\geq 0.21$ ) had an AUC of 0.69 and 0.66 , respectively.

Almost all single frailty items were associated with survival (Tables 1, 4). Mobility-related items of the frailty phenotype (e.g., walking speed and physical activity) were more strongly associated with both mortality and the FI than the other items (e.g., grip strength, weight loss, and exhaustion). The forward regression analysis showed that a broad range of variables, including walking stairs, present at the day care center, panic attacks, asthma/COPD and hemoglobin, and fast fatigue, were selected as independent predictors for survival (Table 7). 
Table 3 Hazard ratio's for 5-year all-cause mortality according to the three level frailty index, using three sets of cut-off values, and the frailty phenotype

\begin{tabular}{|c|c|c|c|c|c|c|c|c|c|c|c|c|}
\hline \multirow[t]{2}{*}{$\begin{array}{l}\text { Frailty } \\
\text { measure }\end{array}$} & \multirow[t]{2}{*}{ Status } & \multicolumn{2}{|c|}{$\begin{array}{l}N=818 \\
\dagger=164\end{array}$} & \multicolumn{3}{|c|}{ Single frailty instrument } & \multicolumn{3}{|c|}{ Both frailty instruments } & \multicolumn{3}{|c|}{ Motor disability } \\
\hline & & $\begin{array}{l}\mathrm{n} \\
\mathrm{cat}\end{array}$ & $\begin{array}{l}\dagger \\
\text { cat }\end{array}$ & $\begin{array}{l}\mathrm{HR}(95 \% \\
\mathrm{CI})\end{array}$ & Wald & $p$ & $\begin{array}{l}\mathrm{HR}(95 \% \\
\mathrm{CI})\end{array}$ & Wald & $p$ & $\begin{array}{l}\mathrm{HR}(95 \% \\
\mathrm{CI})\end{array}$ & Wald & $p$ \\
\hline \multirow[t]{3}{*}{$\begin{array}{l}\text { Frailty } \\
\text { phenotype }\end{array}$} & Non-frail & 221 & 19 & Reference & & $\begin{array}{l}\text { Trend: } \\
\quad<0.001\end{array}$ & Reference & & $\begin{array}{c}\text { Trend: } \\
0.90\end{array}$ & Reference & & $\begin{array}{c}\text { Trend: } \\
0.03\end{array}$ \\
\hline & Pre-frail & 488 & 100 & $\begin{array}{l}2.04 \\
\quad(1.23-3.37)\end{array}$ & 7.74 & 0.005 & $\begin{array}{l}1.12 \\
\quad(0.65-1.92)\end{array}$ & 0.17 & 0.68 & $\begin{array}{l}1.70 \\
\quad(1.01-2.84)\end{array}$ & 4.05 & 0.04 \\
\hline & Frail & 109 & 45 & $\begin{array}{l}4.20 \\
\quad(2.39-7.39)\end{array}$ & 24.9 & $<0.001$ & $\begin{array}{l}1.16 \\
\quad(0.62-2.19)\end{array}$ & 0.22 & 0.64 & $\begin{array}{l}2.31 \\
\quad(1.24-4.32)\end{array}$ & 6.96 & 0.008 \\
\hline \multirow[t]{3}{*}{$\begin{array}{l}\text { Frailty } \\
\text { index }\end{array}$} & $<0.2$ & 295 & 19 & Reference & & $\begin{array}{l}\text { Trend: } \\
\quad<0.001\end{array}$ & Reference & & $<0.001$ & Reference & & $<0.001$ \\
\hline & $0.2-0.35$ & 317 & 44 & $\begin{array}{l}2.27 \\
\quad(1.31-3.93)\end{array}$ & 8.52 & 0.005 & $\begin{array}{l}2.19 \\
\quad(1.24-3.87)\end{array}$ & 7.20 & 0.007 & $\begin{array}{l}2.22 \\
\quad(1.28-3.85)\end{array}$ & 7.96 & 0.005 \\
\hline & $>0.35$ & 206 & 101 & $\begin{array}{l}10.3 \\
\quad(5.97-17.9)\end{array}$ & 69.6 & $<0.001$ & $\begin{array}{l}9.66 \\
\quad(5.23-17.8)\end{array}$ & 52.5 & $<0.001$ & $\begin{array}{l}8.53 \\
\quad(4.69-15.5)\end{array}$ & 49.4 & $<0.001$ \\
\hline \multirow[t]{3}{*}{$\begin{array}{l}\text { Frailty } \\
\text { phenotype }\end{array}$} & Non-frail & 221 & 19 & Reference & & $\begin{array}{l}\text { Trend: } \\
\quad<0.001\end{array}$ & Reference & & $\begin{array}{c}\text { Trend: } \\
0.019\end{array}$ & Reference & & $\begin{array}{l}\text { Trend: } \\
0.03\end{array}$ \\
\hline & Pre-frail & 488 & 100 & $\begin{array}{l}2.04 \\
\quad(1.23-3.37)\end{array}$ & 7.74 & 0.005 & $\begin{array}{l}1.42 \\
\quad(0.84-2.38)\end{array}$ & 1.71 & 0.008 & $\begin{array}{l}1.70 \\
\quad(1.01-2.84)\end{array}$ & 4.05 & 0.04 \\
\hline & Frail & 109 & 45 & $\begin{array}{l}4.20 \\
\quad(2.39-7.39)\end{array}$ & 24.9 & $<0.001$ & $\begin{array}{l}2.21 \\
\quad(1.23-4.00)\end{array}$ & 6.93 & 0.02 & $\begin{array}{l}2.31 \\
\quad(1.24-4.32)\end{array}$ & 6.96 & 0.008 \\
\hline \multirow[t]{3}{*}{$\begin{array}{l}\text { Frailty } \\
\text { index }\end{array}$} & $\leq 0.08$ & 28 & 2 & Reference & & $\begin{array}{l}\text { Trend: } \\
\quad<0.001\end{array}$ & Reference & & $\begin{array}{l}\text { Trend: } \\
\quad<0.001\end{array}$ & Reference & & $\begin{array}{l}\text { Trend: } \\
\quad<0.001\end{array}$ \\
\hline & $0.08-0.25$ & 398 & 32 & $\begin{array}{l}0.94 \\
\quad(0.22-3.99)\end{array}$ & 0.01 & 0.94 & $\begin{array}{l}0.84 \\
\quad(0.20-3.58)\end{array}$ & 0.06 & 0.81 & $\begin{array}{l}0.96 \\
\quad(0.23-4.08)\end{array}$ & 0.00 & 0.96 \\
\hline & $\geq 0.25$ & 392 & 130 & $\begin{array}{l}3.98 \\
\quad(0.95-16.7)\end{array}$ & 3.55 & 0.06 & $\begin{array}{l}2.93 \\
\quad(0.67-12.7)\end{array}$ & 2.06 & 0.15 & $\begin{array}{l}3.15 \\
\quad(0.74-13.4)\end{array}$ & 2.42 & 0.12 \\
\hline \multirow[t]{3}{*}{$\begin{array}{l}\text { Frailty } \\
\text { phenotype }\end{array}$} & Non-frail & 221 & 19 & Reference & & $\begin{array}{l}\text { Trend: } \\
\quad<0.001\end{array}$ & Reference & & $\begin{array}{l}\text { Trend: } \\
0.001\end{array}$ & Reference & & $\begin{array}{c}\text { Trend: } \\
0.03\end{array}$ \\
\hline & Pre-frail & 488 & 100 & $\begin{array}{l}2.04 \\
\quad(1.23-3.37)\end{array}$ & 7.74 & 0.005 & $\begin{array}{l}1.46 \\
(0.87-2.43)\end{array}$ & 2.05 & 0.54 & $\begin{array}{l}1.70 \\
\quad(1.01-2.84)\end{array}$ & 4.05 & 0.04 \\
\hline & Frail & 109 & 45 & $\begin{array}{l}4.20 \\
\quad(2.39-7.39)\end{array}$ & 24.9 & $<0.001$ & $\begin{array}{l}2.56 \\
\quad(1.44-4.56)\end{array}$ & 10.2 & 0.03 & $\begin{array}{l}2.31 \\
\quad(1.24-4.32)\end{array}$ & 6.96 & 0.008 \\
\hline \multirow[t]{3}{*}{$\begin{array}{l}\text { Frailty } \\
\text { index }\end{array}$} & $\leq 0.10$ & 56 & 2 & Reference & & $\begin{array}{l}\text { Trend: } \\
\quad<0.001\end{array}$ & Reference & & $\begin{array}{l}\text { Trend: } \\
\quad<0.001\end{array}$ & Reference & & $\begin{array}{l}\text { Trend: } \\
\quad<0.001\end{array}$ \\
\hline & $0.10-0.21$ & 260 & 19 & $\begin{array}{l}1.79 \\
\quad(0.41-7.75)\end{array}$ & 0.61 & 0.44 & $\begin{array}{l}1.59 \\
\quad(0.36-6.96)\end{array}$ & 0.39 & 0.15 & $\begin{array}{l}1.86 \\
\quad(0.43-8.05)\end{array}$ & 0.69 & 0.41 \\
\hline & $\geq 0.21$ & 502 & 143 & $\begin{array}{l}6.55 \\
\quad(1.58-27.2)\end{array}$ & 6.72 & 0.01 & $\begin{array}{l}4.79 \\
\quad(1.12-20.4)\end{array}$ & 4.48 & 0.001 & $\begin{array}{l}5.31 \\
\quad(1.27-22.2)\end{array}$ & 5.25 & 0.02 \\
\hline
\end{tabular}

Note HR hazard ratio, CI confidence interval, $\dagger$ the total number of deceased participants, the non-frail state was used a reference category for each frailty instrument. All models were adjusted for age, gender, level of ID, and Down syndrome. Participants were excluded if they had missing data on one of the frailty instruments, motor disabilities, or other covariates $(n=232)$. The model motor disability was adjusted for the level of motor impairment, 'no walking impairment' was used as a reference category; the model for motor disability included only the frailty phenotype or the frailty index

\section{Motor disability and frailty}

Information on mobility was known for 989 participants. At baseline, 731 (74\%) participants walked independently, 151 (15\%) walked with support, and $107(11 \%)$ were wheelchair dependent. Those who walked with support were 2.03 (95\% $\mathrm{CI}=1.40-2.97)$ times, and those who were wheelchair dependent were 4.10 (95\% CI $=2.83-5.96)$ times, more likely to have deceased during the follow-up compared to those who walked independently. The last column in Table 3 shows the relation of the two frailty approaches with survival, independent of motor disability at baseline. Although both approaches remain significantly related with mortality, the frailty phenotype loses much of its predictive value. 


\section{Discussion}

In this prospective population-based study, we compared two concepts of frailty in older people with ID: the frailty phenotype and the FI. The FI was more often feasible in the ID population than the frailty phenotype. Both instruments were valid in terms of predicted value for survival; participants classified as frail by either instrument had increased 5 -year mortality risks. Even so, people designated as frail by the FI were more likely to decease than those designated as frail by the frailty phenotype. However, the CIs for the FI were wider than the CIs observed for the frailty phenotype, indicating a larger uncertainty in the estimation. Motor disabilities are an important risk factor for mortality. After adjusting the survival models for motor disability, both, but mainly the frailty phenotype, lost predictive value. Previously, we suggested that the FI might be a more suitable concept for this population because of lifelong disabilities (Evenhuis et al. 2013). The current results confirm this suggestion.

The FI could be calculated for $94 \%$ of the participants, whereas the frailty phenotype was feasible in $81 \%$. For less than a third of the participants ( $29 \%)$, all frailty phenotype criteria could be measured. This is in agreement with results from studies among assisted-living participants, where nearly $40 \%$ could not complete the assessment (de la RicaEscuin et al. 2014; Hogan et al. 2012). This dropout was mainly caused by more severe cognitive impairment and chronic comorbidity. This result is in line with results observed in the general population: persons in whom the phenotype cannot be measured completely are significantly more disabled, have more chronic diseases, are more likely to die, and have a higher FI-score (Collerton et al. 2012; Ravindrarajah et al. 2013). On the other hand, dropout for the FI appeared to be random. The agreement between the two instruments was lower compared to other studies (Theou and Rockwood 2015) and the associations between each single frailty phenotype measure and the FI were rather weak, in contrast to others (Hoogendijk et al. 2015).

In accordance with findings in the general population, we found that the predictive value and thereby the criterion validity for the FI is stronger than that of the frailty phenotype (Blodgett et al. 2015; Hogan et al. 2012; Kulminski et al. 2008; Rockwood et al. 2007; Theou and Rockwood 2015; Woo et al. 2012). There are several explanations for our results.

First, the FI has a much broader approach than the frailty phenotype. It includes all factors that are considered important for frailty (e.g., nutritional status, physical activity, energy, cognition) (de Vries et al. 2011; Gobbens et al. 2010). In contrast, the frailty phenotype focuses on physical frailty only. It appears that, among the highly heterogeneous ID population, physical parameters do only explain part of the variance. Indeed, our forward regression analysis implies that, although physical variables are extremely important, disabilities, diseases, and cognition independently add to the explained variance of the model.

Second, and in line with the first suggestion, the frailty phenotype seems to be too determined by mobility limitations. Indeed, in our study the frailty phenotype had only limited additional predictive value to motor disabilities alone. This limits the predictive value of the frailty phenotype, because motor disabilities appear to be less strong predictors for mortality in our ID sample than observed in the general population (Feeny et al. 2012; Majer et al. 2011). Lifelong or early motor impairment, which is common in this population, is likely to be less predictive than motor impairment acquired in later life.

Third, the phenotype approach has the advantage that it focuses on five core clinical features, that are, in theory, easy to measure. Nevertheless, these pre-defined elements are not measurable in all individuals with an ID. This appears less of a problem with the FI approach, which does not require the use of a pre-defined set of variables or even the same number of variables (Rockwood et al. 2006). We were therefore able to design an FI for the ID population, whereas the elements of the frailty phenotype are designed for the general population.

Fourth, we were unable to apply the exact parameters as those proposed in the Cardiovascular Health Study to measure the frailty phenotype. This could have led to an unknown shift in its predictive validity (Theou et al. 2015). In addition, the analyses were applied to participants with at least three elements of the frailty phenotype measured. It is likely that this caused an underestimation of the true frailty prevalence. Measurements that are more feasible for the ID population might have increased the predictive validity of the frailty phenotype. For example, it is known that physical activity is hard to measure with pedometers in people with ID (Hilgenkamp et al. 2012). Using an instrument such as the StepWatch or GPS could have led to more valid results for the element 'physical activity' (van Schijndel-Speet et al. submitted).

Nevertheless, overall the frailty phenotype showed a strong relation with mortality, indicating that physical fitness and mobility are important to lengthen the lifespan. Specifically, the mobility-related frailty phenotype items (e.g., walking speed and physical inactivity) were most strongly associated with both mortality and the FI. The group with low physical activity and low walking speed also includes those bound to a wheelchair. These results indicate that even though mobility impairment is less predictive for mortality than observed in the general population, it is a very important risk factor for mortality and overall health (e.g., the FI). It has been shown in the HA-ID 
study that elements from the frailty phenotype (e.g., grip strength, walking speed) predict disability in mobility and activities of daily living (Oppewal et al. 2014). In the general population, physical activity and fitness can reduce or prevent frailty (Liu and Fielding 2011; Theou et al. 2011). Whether increased physical fitness and activity will also reduce or delay frailty in people with ID needs to be investigated.

The main strength of our study is its large-scale and prospective population-based design, in which we used standardized and internationally accepted methods to measure frailty. Nevertheless, several limitations need to be taken into account. First, although the population was near-representative, older people with ID using specialized support, living independently or with relatives were slightly underrepresented in the HA-ID study. Because of the high correlation between frailty and more severe ID, this underrepresentation might have caused slightly higher prevalence of frailty (Hilgenkamp et al. 2011). Second, we did not take into account time and costs as feasibility aspects. It is very likely that regarding costs, the frailty phenotype is more feasible for clinical practice. Nevertheless, with this study we mainly wanted to better understand frailty and its consequences in this population. For the clinical implementation of any frailty instrument, time and cost should be taken into account. Third, we studied the relation between frailty and survival because mortality is an easily verifiable, dichotomous, and nonarbitrary outcome. Nevertheless, other health outcomes including care need, hospitalization, and disabilities are needed to obtain full insight into the negative consequences of frailty in people with ID. Fourth, the frailty phenotype and the FI are the two most commonly applied concepts. Nevertheless, there are other concepts and frailty instruments that were not included in this study. These measures were chosen because they allow objective measurements, which are needed in a population where only about $25 \%$ is capable of reliable, self-report. In addition, the baseline data of the HA-ID study were already collected before frailty became of interest. Therefore, we were limited to frailty instruments that could be constructed using the available data. In addition, there is value using the two most commonly used measurements in connecting to a large body of published work in order to compare population characteristics. Last, it has been advised to use the FI as a continuous scale, and not apply cut points. Even so, for the sake of comparing the FI with the three frailty strata, proposed by Fried et al., we created three frailty groups applying three different cut points. Nevertheless, the cut points that classified individuals as robust if the FI was below 0.10 or 0.08 resulted in small groups of robust participants and, in line with expectations regarding these robust individuals, limited number of deaths were observed. Using the robust group as a reference group was therefore complicated and resulted in underpowered HRs. We therefore placed most emphasis on the first applied cut value (robust if FI was below 0.20). In order to better understand the agreement and validation of different cut points, a longer follow-up and/or more participants are required.

The two frailty concepts used in our study have a different purpose and different underlying justification. Nevertheless, by comparing the two different concepts, we tried to improve the understanding of frailty in people with ID. The cycle of frailty, which serves as the biological basis of the frailty phenotype, might not be the only relevant aspect in the ID population. Mainly because in this cycle of age-related decline, it is supposed that its individual components are associated with each other and with further physiological losses, disability, dependency, and eventually death. In contrast, in our population motor disabilities can be lifelong and congenital and childhood disabilities are more likely to contribute to frailty than the other way around. For example, it was observed that, according to the frailty phenotype, people with motor disabilities were very likely to also be frail or pre-frail; only $8 \%$ of the participants using a walking aid or wheelchair were classified as robust (Evenhuis et al., 2012). The FI, within clearly defined borders, simply counts how many things are wrong with an individual. Even though the FI also includes lifelong disabilities, it seems that these lifelong problems less influence its validity. Nevertheless, also in people with ID, disabilities increase as a consequence of aging and frailty (Schoufour et al. 2014, 2015). Therefore, identifying frail individuals can assist clinicians in identifying people at risk for adverse health outcomes, who may thereafter benefit from interventions.

Although efforts have been made, there is not yet a validated frailty screening instrument for the ID population (Brehmer-Rinderer et al. 2013). Screening and monitoring the health status of people with ID can potentially have great beneficial effects because recovering from a frail state is complicated, putting more emphasis on early detection and prevention (Rockwood et al. 2011). As the FI provides the highest feasibility and the highest predictive validity, we advise to screen for frailty using an FI like approach. Nevertheless, several steps need to be taken into account before the FI can be applicable to clinical practice. The original FI is composed of 51 items, of which some are not applicable to clinical practice (for example, the block test to measure manual dexterity and the DDS questionnaire to diagnose dysphagia). It should be studied whether the FI remains valid after the removal of less clinically applicable measures. Also, the stability of the FI should be tested by determining the test-retest reliability. Additionally, it is yet 
unclear if the FI is sensitive to changes over time. In the long run, routinely collected data might be used to calculate an FI and monitor frailty status over time.

With this study, we aimed to better understand frailty in people with ID by applying two different frailty instruments. Our results imply that the used FI is a stronger predictor for mortality than our adaptation of the phenotype in the population of older people with ID. Possible explanations of our findings are that we did not use the exact frailty phenotype variables or that the FI includes multiple health domains. The differences between the two frailty approaches may also be caused by the FI being less determined by lifelong disability and mobility, compared to the frailty phenotype. We suggest that future studies on frailty in people with ID take into account that the feasibility of frailty instruments can be hampered, and adapted instruments are required. Furthermore, lifelong disabilities, such as mobility impairment, could influence the prevalence of frailty and the validity of frailty instruments. Although we acknowledge mobility impairment as a very important aspect of frailty, we suggest using multiple frailty domains, in order to capture the risk for mortality the best. Future research needs to focus on the clinical feasibility of the FI. Particularly, it should be studied whether routinely collected data can be used to construct an FI for people with ID.
Funding This study was supported by a grant from the National Care for the Elderly Programme (NPO) which is part of the Netherlands Organisation for Health Research and Development (ZonMW; Nos. 57000003, 314030302). Further support was provided by the three participating care organizations (Abrona, Ipse de Bruggen, and Amarant).

\section{Compliance with ethical standards}

Conflict of interests The authors declare that there is no conflict of interest.

Ethics approval This study was approved by the Ethics Committee of the Erasmus Medical Center Rotterdam (MEC-2008-234) and the ethics committees of the participating care organizations (Abrona, Ipse de Bruggen, and Amarant).

Open Access This article is distributed under the terms of the Creative Commons Attribution 4.0 International License (http://crea tivecommons.org/licenses/by/4.0/), which permits unrestricted use, distribution, and reproduction in any medium, provided you give appropriate credit to the original author(s) and the source, provide a link to the Creative Commons license, and indicate if changes were made.

\section{Appendix}

See Tables 4, 5, 6, and 7 .

Table 4 Overview of deficits included in the frailty index $(n=982)$

\begin{tabular}{|c|c|c|c|c|c|c|}
\hline$\#$ & Deficit & Additional information & Cut-off values and FI scores & $\begin{array}{l}\text { Percentage per } \\
\text { category }\end{array}$ & $\operatorname{HR}(95 \% \mathrm{CI})^{\mathrm{a}}$ & $p$ (for trend) \\
\hline 1 & Bladder control & $\begin{array}{l}\text { ADL, Completed by } \\
\text { professional caregivers } \\
\text { of the participants }\end{array}$ & $\begin{array}{l}\text { Incontinent }=1 \\
\text { Sometimes continent }=0.5 \\
\text { Continent }=0\end{array}$ & $\begin{array}{l}23.1 \\
24.1 \\
52.7\end{array}$ & $\begin{array}{l}3.86(2.70-5.52) \\
1.39(0.92-2.08) \\
-\end{array}$ & $<0.001$ \\
\hline 2 & Dressing & $\begin{array}{l}\text { ADL, Completed by } \\
\text { professional caregivers } \\
\text { of the participants }\end{array}$ & $\begin{array}{l}\text { Needs help }=1 \\
\text { Partly with help }=0.5 \\
\text { No help }=0\end{array}$ & $\begin{array}{l}19.0 \\
25.8 \\
55.2\end{array}$ & $\begin{array}{l}5.48(3.70-8.13) \\
2.04(1.38-3.02) \\
-\end{array}$ & $<0.001$ \\
\hline 3 & Walking stairs & $\begin{array}{l}\text { ADL, Completed by } \\
\text { professional caregivers } \\
\text { of the participants }\end{array}$ & $\begin{array}{l}\text { Needs help }=1 \\
\text { Partly with help }=0.5 \\
\text { No help }=0\end{array}$ & $\begin{array}{l}27.6 \\
20.7 \\
51.7\end{array}$ & $\begin{array}{l}4.53(3.12-6.58) \\
1.75(1.12-2.73) \\
-\end{array}$ & $<0.001$ \\
\hline 4 & Bathing & $\begin{array}{l}\text { ADL, Completed by } \\
\text { professional caregivers } \\
\text { of the participants }\end{array}$ & $\begin{array}{l}\text { With help }=1 \\
\text { No help }=0\end{array}$ & $\begin{array}{l}64.3 \\
35.7\end{array}$ & $\begin{array}{l}2.50(1.65-3.80) \\
-\end{array}$ & $<0.001$ \\
\hline 5 & Transfer bed to chair & $\begin{array}{l}\text { ADL, Completed by } \\
\text { professional caregivers } \\
\text { of the participants }\end{array}$ & $\begin{array}{l}\text { Unable, no sitting balance }=1 \\
\text { Major help }=0.66 \\
\text { Minor help }=0.33 \\
\text { No help }=0\end{array}$ & $\begin{array}{l}9.4 \\
3.0 \\
13.2 \\
74.4\end{array}$ & $\begin{array}{l}4.79(3.22-7.12) \\
5.17(3.00-8.90) \\
2.71(1.82-4.01) \\
-\end{array}$ & $<0.001$ \\
\hline 6 & Groceries & $\begin{array}{l}\text { IADL, completed by } \\
\text { professional caregivers } \\
\text { of the participants }\end{array}$ & $\begin{array}{l}\text { Not independently }=1 \\
\text { With help }=0.5 \\
\text { Can do groceries }=0\end{array}$ & $\begin{array}{l}51.2 \\
20.9 \\
27.9\end{array}$ & $\begin{array}{l}3.08(1.93-4.93) \\
1.12(0.63-1.98) \\
-\end{array}$ & $<0.001$ \\
\hline 7 & Housekeeping & $\begin{array}{l}\text { IADL, completed by } \\
\text { professional caregivers } \\
\text { of the participants }\end{array}$ & $\begin{array}{l}\text { Not independently }=1 \\
\text { With help }=0.5 \\
\text { Can do housekeeping }=0\end{array}$ & $\begin{array}{l}74.6 \\
15.2 \\
10.2\end{array}$ & $\begin{array}{l}3.75(1.51-9.29) \\
1.58(0.56-4.51) \\
-\end{array}$ & 0.001 \\
\hline
\end{tabular}


Table 4 continued

\begin{tabular}{|c|c|c|c|c|c|c|}
\hline$\#$ & Deficit & Additional information & Cut-off values and FI scores & $\begin{array}{l}\text { Percentage per } \\
\text { category }\end{array}$ & $\operatorname{HR}(95 \% \mathrm{CI})^{\mathrm{a}}$ & $p$ (for trend) \\
\hline 8 & Falling & $\begin{array}{l}\text { Number of falls in the last } \\
\text { three months. } \\
\text { Information gathered } \\
\text { via the professional care } \\
\text { giver }\end{array}$ & $\begin{array}{l}>11 \text { falls }=1 \\
6-10 \text { falls }=0.75 \\
3-5 \text { falls }=0.5 \\
1-2 \text { falls }=0.25 \\
0 \text { falls }=0\end{array}$ & $\begin{array}{l}1.3 \\
1.0 \\
3.8 \\
17.4 \\
76.4\end{array}$ & $\begin{array}{l}2.61(1.07-6.41) \\
1.60(0.39-6.56) \\
2.27(1.27-4.06) \\
1.31(0.91-1.87) \\
-\end{array}$ & 0.016 \\
\hline 9 & $\begin{array}{l}\text { Present at the care } \\
\text { center (max } 10 \\
\text { shifts per week) }\end{array}$ & $\begin{array}{l}\text { Information gathered via } \\
\text { the professional care } \\
\text { giver }\end{array}$ & $\begin{array}{l}<3 \text { visits a week }=1 \\
\geq 3 \text { visits a week }=0\end{array}$ & $\begin{array}{l}15.7 \\
84.3\end{array}$ & $\begin{array}{l}1.82(1.27-2.59) \\
-\end{array}$ & 0.001 \\
\hline 10 & Fatigued & $\begin{array}{l}\text { ADESS (Dutch } \\
\text { translation of the } \\
\text { Anxiety, Depression } \\
\text { And Mood Scale) over } \\
\text { the past six months. } \\
\text { Completed by } \\
\text { professional caregivers }\end{array}$ & $\begin{array}{l}\text { Very often }=1 \\
\text { Often }=0.66 \\
\text { Sometimes }=0.33 \\
\text { Never }=0\end{array}$ & $\begin{array}{l}6.0 \\
17.3 \\
30.9 \\
45.8\end{array}$ & $\begin{array}{l}3.36(3.36-2.06) \\
1.85(1.85-1.24) \\
1.67(1.67-1.17) \\
-\end{array}$ & $<0.001$ \\
\hline 11 & Listless & $\begin{array}{l}\text { ADESS (Dutch } \\
\text { translation of the } \\
\text { Anxiety, Depression } \\
\text { And Mood Scale) over } \\
\text { the past six months. } \\
\text { Completed by } \\
\text { professional caregivers }\end{array}$ & $\begin{array}{l}\text { Very often }=1 \\
\text { Often }=0.66 \\
\text { Sometimes }=0.33 \\
\text { Never }=0\end{array}$ & $\begin{array}{l}3.2 \\
8.6 \\
23.7 \\
64.5\end{array}$ & $\begin{array}{l}3.54(2.05-6.13) \\
1.87(1.19-2.95) \\
1.46(1.04-2.04) \\
-\end{array}$ & $<0.001$ \\
\hline 12 & Panic attacks & $\begin{array}{l}\text { ADESS (Dutch } \\
\text { translation of the } \\
\text { Anxiety, Depression } \\
\text { And Mood Scale) over } \\
\text { the past six months. } \\
\text { Completed by } \\
\text { professional caregivers }\end{array}$ & $\begin{array}{l}\text { Very often }=1 \\
\text { Often }=0.66 \\
\text { Sometimes }=0.33 \\
\text { Never }=0\end{array}$ & $\begin{array}{l}3.4 \\
6.8 \\
13.7 \\
76.1\end{array}$ & $\begin{array}{l}3.47(2.00-6.06) \\
1.44(0.85-2.43) \\
1.71(1.17-2.50) \\
-\end{array}$ & $<0.001$ \\
\hline 13 & $\begin{array}{l}\text { Decreased food } \\
\text { intake, due to loss of } \\
\text { appetite, digestive } \\
\text { problems, chewing } \\
\text { of swallowing } \\
\text { difficulties }\end{array}$ & $\begin{array}{l}\text { Mini Nutritional } \\
\text { Assessment (MNA) } \\
\text { over the past three } \\
\text { months. Completed by } \\
\text { professional caregivers }\end{array}$ & $\begin{array}{l}\text { Severe decrease in food } \\
\text { intake }=1 \\
\text { Moderate decrease in food } \\
\text { intake }=0.5 \\
\text { No decrease in food intake }=0\end{array}$ & $\begin{array}{l}4.3 \\
9.5 \\
86.2\end{array}$ & $\begin{array}{l}2.61(1.61-4.22) \\
1.94(1.31-2.87) \\
-\end{array}$ & $<0.001$ \\
\hline 14 & Weight loss & $\begin{array}{l}\text { Mini Nutritional } \\
\text { Assessment (MNA) } \\
\text { over the past three } \\
\text { months. Completed by } \\
\text { professional caregivers }\end{array}$ & $\begin{array}{l}\text { Weight loss greater than } \\
\quad 3 \mathrm{~kg}=1 \\
\text { Does not know }=0.5 \\
\text { Weight loss } 1-3 \mathrm{~kg}=0.5 \\
\text { No weight loss }=0\end{array}$ & $\begin{array}{l}24.2 \\
71.0\end{array}$ & $\begin{array}{l}2.05(1.20-3.52) \\
1.24(0.90-1.73)\end{array}$ & 0.023 \\
\hline 15 & $\begin{array}{l}\text { Fluid intake per day } \\
\text { (water, juice, coffee, } \\
\text { tea, milk) }\end{array}$ & $\begin{array}{l}\text { Mini Nutritional } \\
\text { Assessment (MNA) } \\
\text { over the past three } \\
\text { months. Completed by } \\
\text { professional caregivers }\end{array}$ & $\begin{array}{l}\text { Less than } 3 \text { cups }=1 \\
1 \text { to } 5 \text { cups }=0.5 \\
>5 \text { cups }=0\end{array}$ & $\begin{array}{l}0.5 \\
14.8 \\
84.6\end{array}$ & $\begin{array}{l}10.9(3.94-30.0) \\
1.13(0.77-1.65) \\
-\end{array}$ & $<0.001$ \\
\hline 16 & $\begin{array}{l}\text { Calf circumference } \\
\text { (CC) in } \mathrm{cm}\end{array}$ & $\begin{array}{l}\text { Mini Nutritional } \\
\text { Assessment (MNA) } \\
\text { Completed by } \\
\text { professional caregivers }\end{array}$ & $\begin{array}{l}\mathrm{CC}<31=1 \\
\mathrm{CC} \geq 31=0\end{array}$ & $\begin{array}{l}21.3 \\
78.7\end{array}$ & $\begin{array}{l}1.92(1.39-2.67) \\
-\end{array}$ & $<0.001$ \\
\hline 17 & $\begin{array}{l}\text { Only eats selected } \\
\text { types of food (e.g., } \\
\text { pudding, rice) }\end{array}$ & $\begin{array}{l}\text { Screening Tool of Eating } \\
\text { Problems (STEP) over } \\
\text { the last month. } \\
\text { Completed by } \\
\text { professional caregivers }\end{array}$ & $\begin{array}{l}>10 \text { times }=1 \\
\text { Between } 1-10 \text { times }=0.5 \\
\text { Not at all/not a problem }=0\end{array}$ & $\begin{array}{l}4.5 \\
3.9 \\
91.6\end{array}$ & $\begin{array}{l}1.73(1.04-2.90) \\
2.84(1.68-4.79) \\
-\end{array}$ & $<0.001$ \\
\hline 18 & $\begin{array}{l}\text { Only eats small } \\
\text { amounts of the } \\
\text { presented food }\end{array}$ & $\begin{array}{l}\text { Screening Tool of Eating } \\
\text { Problems (STEP) over } \\
\text { the last month. } \\
\text { Completed by } \\
\text { professional caregivers }\end{array}$ & $\begin{array}{l}>10 \text { times }=1 \\
\text { Between } 1-10 \text { times }=0.5 \\
\text { Not at all/not a problem }=0\end{array}$ & $\begin{array}{l}4.2 \\
12.2 \\
83.6\end{array}$ & $\begin{array}{l}1.95(1.12-3.41) \\
1.39(0.95-2.04) \\
-\end{array}$ & 0.025 \\
\hline
\end{tabular}


Table 4 continued

\begin{tabular}{|c|c|c|c|c|c|c|}
\hline \# & Deficit & Additional information & Cut-off values and FI scores & $\begin{array}{l}\text { Percentage per } \\
\text { category }\end{array}$ & $\mathrm{HR}(95 \% \mathrm{CI})^{\mathrm{a}}$ & $p$ (for trend) \\
\hline 19 & $\begin{array}{l}\text { Only eats foods of } \\
\text { certain textures }\end{array}$ & $\begin{array}{l}\text { Screening Tool of Eating } \\
\text { Problems (STEP) over } \\
\text { the last month. } \\
\text { Completed by } \\
\text { professional caregivers }\end{array}$ & $\begin{array}{l}>10 \text { times }=1 \\
\text { Between } 1-10 \text { times }=0.5 \\
\text { Not at all/not a problem }=0\end{array}$ & $\begin{array}{l}5.4 \\
2.5 \\
92.1\end{array}$ & $\begin{array}{l}2.61(1.65-4.14) \\
2.36(1.26-4.39) \\
-\end{array}$ & $<0.001$ \\
\hline 20 & Mobility & $\begin{array}{l}\text { Provided by professional } \\
\text { caregivers }\end{array}$ & $\begin{array}{l}\text { Wheelchair }=1 \\
\text { Walks with support }=0.5 \\
\text { Walks independently }=0\end{array}$ & $\begin{array}{l}10.9 \\
15.3 \\
73.8\end{array}$ & $\begin{array}{l}4.10(2.83-5.96) \\
2.04(1.40-2.97) \\
-\end{array}$ & $<0.001$ \\
\hline 21 & CVA & $\begin{array}{l}\text { Medical file, last } \\
24 \text { months }\end{array}$ & $\begin{array}{l}\text { Yes }=1 \\
\text { No }=0\end{array}$ & $\begin{array}{l}94.0 \\
6.0\end{array}$ & $\begin{array}{l}1.57(0.95-2.59) \\
-\end{array}$ & 0.080 \\
\hline 22 & $\begin{array}{l}\text { Coronary heart } \\
\text { diseases/heart } \\
\text { failure/cardiac } \\
\text { dysrhythmia/ } \\
\text { pacemaker }\end{array}$ & $\begin{array}{l}\text { Medical file, last } \\
24 \text { months }\end{array}$ & $\begin{array}{l}\text { Yes }=1 \\
\text { No }=0\end{array}$ & $\begin{array}{l}9.2 \\
90.8\end{array}$ & $\begin{array}{l}2.26(1.51-3.38) \\
-\end{array}$ & $<0.001$ \\
\hline 23 & Cancer & Medical file, entire life & $\begin{array}{l}\text { Yes }=1 \\
\text { No }=0\end{array}$ & $\begin{array}{l}4.9 \\
95.1\end{array}$ & $\begin{array}{l}1.27(0.70-2.31) \\
-\end{array}$ & 0.43 \\
\hline 24 & Asthma/COPD & $\begin{array}{l}\text { Medical file, last } \\
24 \text { months, mediation }\end{array}$ & $\begin{array}{l}\text { Yes }=1 \\
\text { No }=0\end{array}$ & $\begin{array}{l}13.2 \\
86.8\end{array}$ & $\begin{array}{l}2.27(1.60-3.24) \\
-\end{array}$ & $<0.001$ \\
\hline 25 & GERD & $\begin{array}{l}\text { Medical file, last } \\
24 \text { months }\end{array}$ & $\begin{array}{l}\text { Yes }=1 \\
\text { No }=0\end{array}$ & $\begin{array}{l}20.0 \\
80.0\end{array}$ & $\begin{array}{l}1.52(1.07-2.15) \\
-\end{array}$ & 0.02 \\
\hline 26 & Obstipation & $\begin{array}{l}\text { Medical file, last } \\
24 \text { months, medication }\end{array}$ & $\begin{array}{l}\text { Yes }=1 \\
\text { No }=0\end{array}$ & $\begin{array}{l}39.7 \\
60.3\end{array}$ & $\begin{array}{l}2.02(1.48-2.76) \\
-\end{array}$ & $<0.001$ \\
\hline 27 & $\begin{array}{l}\text { Risk for Diabetes } \\
\text { Mellitus (DM) or } \\
\text { known DM }\end{array}$ & $\begin{array}{l}\text { Medical file, blood } \\
\text { glucose levels, } \\
\text { medication }\end{array}$ & $\begin{array}{l}\text { DM according to medical file or } \\
\text { taking drugs for } \mathrm{DM} \text { and/or } \\
\text { serum glucose } \geq 7 \mathrm{mmol} / \\
1=1 \\
\text { No DM according to medial file, } \\
\text { no DM drugs and blood } \\
\text { glucose } 6.1-6.9=0.5 \\
\text { No DM according to medial file, } \\
\text { no DM drugs and blood } \\
\text { glucose }<6.1=0\end{array}$ & 84.8 & $0.90(0.33-2.43)$ & 0.75 \\
\hline 28 & Scoliosis & Medical file & $\begin{array}{l}\text { Yes }=1 \\
\text { No }=0\end{array}$ & $\begin{array}{l}10.6 \\
89.4\end{array}$ & $\begin{array}{l}1.27(0.81-1.99) \\
-\end{array}$ & 0.30 \\
\hline 29 & $\begin{array}{l}\text { Visual/Hearing } \\
\text { impairments } \\
\text { (V/H impairment) }\end{array}$ & Medical file & $\begin{array}{l}\text { At least one severe } \mathrm{V} / \mathrm{H} \\
\text { impairment }=1 \\
\text { Two moderate } \mathrm{V} / \mathrm{H} \\
\text { impairment }=1 \\
\text { One moderate } \mathrm{V} / \mathrm{H} \\
\text { impairment }=0.5 \\
\text { No } \mathrm{V} / \mathrm{H} \text { impairment }=0\end{array}$ & $\begin{array}{l}29.9 \\
45.5\end{array}$ & $\begin{array}{l}1.56(1.04-2.33) \\
-\end{array}$ & 0.023 \\
\hline 30 & $\begin{array}{l}\text { Medication use } \\
\text { (polypharmacy) }\end{array}$ & Medical file & $\begin{array}{l}\geq 7 \text { drugs }=1 \\
4-6 \text { drugs }=0.5 \\
0-3 \text { drugs }=0\end{array}$ & $\begin{array}{l}19.8 \\
31.2 \\
48.9\end{array}$ & $\begin{array}{l}3.12(2.13-4.67) \\
1.75(1.21-2.52) \\
-\end{array}$ & $<0.001$ \\
\hline 31 & Over or under weight & Medical examination & $\begin{array}{l}\text { BMI }<18.5 \text { OR }>30=1 \\
\text { BMI } 18.5-20 \text { OR } 25-30=0.5 \\
\text { BMI } 20-25=0\end{array}$ & $\begin{array}{l}27.7 \\
41.0 \\
31.3\end{array}$ & $\begin{array}{l}1.44(0.93-2.23) \\
1.01(0.68-1.51) \\
-\end{array}$ & 0.15 \\
\hline 32 & High blood pressure & Medical file & $\begin{array}{l}\text { Yes }=1 \\
\text { No }=0\end{array}$ & $\begin{array}{l}21.5 \\
78.5\end{array}$ & $\begin{array}{l}0.94(0.64-1.39) \\
-\end{array}$ & 0.76 \\
\hline 33 & $\begin{array}{l}\text { Peripheral } \\
\text { atherosclerosis }\end{array}$ & Medical examination & $\begin{array}{l}\text { Ankle Arm index } \\
>0.9=1 \\
0.8-0.9=0.5 \\
<0.8=0\end{array}$ & $\begin{array}{l}9.9 \\
12.2 \\
78.0\end{array}$ & $\begin{array}{l}1.90(1.15-3.15) \\
1.86(1.17-2.97) \\
-\end{array}$ & 0.005 \\
\hline
\end{tabular}


Table 4 continued

\begin{tabular}{|c|c|c|c|c|c|c|}
\hline$\#$ & Deficit & Additional information & Cut-off values and FI scores & $\begin{array}{l}\text { Percentage per } \\
\text { category }\end{array}$ & $\operatorname{HR}(95 \% \mathrm{CI})^{\mathrm{a}}$ & $p$ (for trend) \\
\hline 34 & Osteoporosis $(t$-score $)$ & Medical examination & $\begin{array}{l}<2.5=1 \\
-1 \text { till }-2.5=0.5 \\
>-1=0\end{array}$ & $\begin{array}{l}32.7 \\
38.8 \\
28.6\end{array}$ & $\begin{array}{l}1.14(0.72-1.81) \\
0.72(0.45-1.14) \\
-\end{array}$ & 0.109 \\
\hline 35 & $\begin{array}{l}\text { Manual Dexterity } \\
\text { (BBT) }\end{array}$ & $\begin{array}{l}\text { Fitness assessment } \\
\text { The participants were } \\
\text { asked to move as many } \\
\text { colored blocks as } \\
\text { possible in one minute. } \\
\text { The blocks were } \\
2.5 \mathrm{~cm}^{3} \text { and needed to } \\
\text { be moved from one side } \\
\text { of a wooden box to the } \\
\text { other side }\end{array}$ & $\begin{array}{l}\text { Lowest quartile }=1 \\
\text { Second quartile }=0.66 \\
\text { Third quartile }=0.33 \\
\text { Highest quartile }=0\end{array}$ & $\begin{array}{l}26.8 \\
21.6 \\
26.1 \\
25.7\end{array}$ & $\begin{array}{l}2.75(1.51-5.00) \\
1.04(0.55-1.97) \\
0.83(0.45-1.53) \\
-\end{array}$ & $<0.001$ \\
\hline 36 & Walking speed & $\begin{array}{l}\text { Fitness assessment } \\
\text { Comfortable walking } \\
\text { speed was measured by } \\
\text { the average of three } \\
\text { records of the time } \\
\text { needed to complete } 5 \\
\text { meters after } 3 \text { meters } \\
\text { for acceleration }\end{array}$ & $\begin{array}{l}\text { Slow walking speed was } \\
\text { Stratified for height and gender } \\
\text { Male } \\
\text { height } \leq 173 \mathrm{~cm} \geq 7 \mathrm{~s}=1 \\
\text { Male } \\
\text { height }>173 \mathrm{~cm} \geq 6 \mathrm{~s}=1 \\
\text { Females } \\
\text { height } \leq 159 \mathrm{~cm} \geq 7 \mathrm{~s}=1 \\
\text { Females }>159 \mathrm{~cm} \geq 6 \mathrm{~s}=1 \\
\text { Faster }=0 \\
\text { Participant who were not able to } \\
\text { succeed the walking speed } \\
\text { assessment due to physical } \\
\text { limitations were scored positive } \\
\text { (score 1) as well } \\
\text { Slow walking speed was } \\
\text { Stratified for height and gender }\end{array}$ & 35.3 & $3.27(2.27-4.71)$ & $<0.001$ \\
\hline 37 & Grip strength & $\begin{array}{l}\text { Fitness assessment } \\
\text { Measured with a Jamar } \\
\text { Hand Dynamometer } \\
\text { (\#5030J1, Sammons } \\
\text { Preston Rolyan, USA) }\end{array}$ & $\begin{array}{l}\text { Grip strength was stratified for } \\
\text { gender and BMI } \\
\text { Below cut-off values }=1 \\
\text { Male } \\
\text { BMI } \leq 24: \geq 29 \mathrm{~kg}=0 \\
\text { BMI 24.1-26: } \geq 30 \mathrm{~kg}=0 \\
\text { BMI 26.1-28: } \geq 30 \mathrm{~kg}=0 \\
\text { BMI }>28: \geq 32 \mathrm{~kg}=0 \\
\text { Female } \\
\text { BMI } \leq 23: \geq 17 \mathrm{~kg}=0 \\
\text { BMI 23.1-26: } \geq 17.3 \mathrm{~kg}=0 \\
\text { BMI 26.1-29: } \geq 18 \mathrm{~kg}=0 \\
\text { BMI }>29: \geq 21 \mathrm{~kg}=0 \\
\text { Participant who were not able to } \\
\text { succeed the grip strength } \\
\text { assessment due to physical } \\
\text { limitations were scored positive } \\
\text { (score 1) as well }\end{array}$ & $\begin{array}{l}52.9 \\
47.1\end{array}$ & $1.32(0.86-2.03)$ & 0.21 \\
\hline 38 & Hypercholesterolemia & Medical registry & $\begin{array}{l}\text { Yes }=1 \\
\text { No }=0\end{array}$ & $\begin{array}{l}10.0 \\
90.0\end{array}$ & $\begin{array}{l}0.58(0.30-1.11) \\
-\end{array}$ & 0.58 \\
\hline
\end{tabular}


Table 4 continued

\begin{tabular}{|c|c|c|c|c|c|c|}
\hline$\#$ & Deficit & Additional information & Cut-off values and FI scores & $\begin{array}{l}\text { Percentage per } \\
\text { category }\end{array}$ & $\operatorname{HR}(95 \% \mathrm{CI})^{\mathrm{a}}$ & $p$ (for trend) \\
\hline 39 & HDL & Blood examination & $\begin{array}{l}\text { HDL was stratified for gender } \\
\text { Male } \\
0-0.9 \mathrm{mmol} / \mathrm{l}=1 \\
0.9-1.55 \mathrm{mmol} / \mathrm{L}=0.5 \\
>1.55 \mathrm{mmol} / \mathrm{L}=0 \\
\text { Female } \\
0-1.1 \mathrm{mmol} / \mathrm{l}=1 \\
1.1-1.55 \mathrm{mmol} / \mathrm{L}=0.5 \\
>1.55 \mathrm{mmol} / \mathrm{L}=0\end{array}$ & $\begin{array}{l}24.6 \\
59.0 \\
16.4\end{array}$ & $\begin{array}{l}1.17(0.69-1.98) \\
0.92(0.56-1.50) \\
-\end{array}$ & 0.49 \\
\hline 40 & Hemoglobin & Blood examination & $\begin{array}{l}\text { Stratified for gender } \\
\text { Male } \\
8.6-10.5 \mathrm{mmol} / \mathrm{L}=0 \\
<8.6 \mathrm{OR}>10.5 \mathrm{mmol} / \mathrm{L}=1 \\
\text { Female } \\
7.5-9.5 \mathrm{mmol} / \mathrm{L}=0 \\
<7.5 \mathrm{OR}>9.5 \mathrm{mmol} / \mathrm{L}=1\end{array}$ & $\begin{array}{l}23.8 \\
76.2\end{array}$ & $\begin{array}{l}2.67(1.87-3.08) \\
-\end{array}$ & $<0.001$ \\
\hline 41 & Dysphagia & $\begin{array}{l}\text { Diagnosis via DDS } \\
\text { questionnaire }\end{array}$ & $\begin{array}{l}\text { Severe dysphagia }=1 \\
\text { Moderate dysphagia }=0.5 \\
\text { No Dysphagia }=0\end{array}$ & $\begin{array}{l}52.0 \\
26.1 \\
21.8\end{array}$ & $\begin{array}{l}2.10(1.29-3.42) \\
1.52(0.88-2.63) \\
-\end{array}$ & 0.006 \\
\hline 42 & Hospitalization & $\begin{array}{l}\text { Asked in informed } \\
\text { consent form. } \\
\text { Hospitalization is the } \\
\text { past } 12 \text { months }\end{array}$ & $\begin{array}{l}>2=1 \\
1-2=0.5 \\
\text { No }=0\end{array}$ & $\begin{array}{l}0.6 \\
11.0 \\
88.4\end{array}$ & $\begin{array}{l}8.57(2.59-28.3) \\
1.74(1.16-2.62) \\
-\end{array}$ & $<0.001$ \\
\hline 43 & $\begin{array}{c}\text { Makes a sad/ } \\
\text { depressing } \\
\text { impression }\end{array}$ & $\begin{array}{l}\text { SDZ, completed by } \\
\text { professional caregivers } \\
\text { Last three months }\end{array}$ & $\begin{array}{l}\text { Often }=1 \\
\text { Several times }=0.66 \\
\text { Sometimes }=0.33 \\
\text { Never/very rare }=0\end{array}$ & $\begin{array}{l}4.6 \\
12.9 \\
36.9 \\
45.6\end{array}$ & $\begin{array}{l}4.54(2.48-7.94) \\
1.97(1.23-3.15) \\
1.87(1.31-2.68) \\
-\end{array}$ & $<0.001$ \\
\hline 44 & $\begin{array}{l}\text { Has fun and interest in } \\
\text { daily activities }\end{array}$ & $\begin{array}{l}\text { SDZ, completed by } \\
\text { professional caregivers } \\
\text { Last three months }\end{array}$ & $\begin{array}{l}\text { Never/very rare }=1 \\
\text { Sometimes }=0.66 \\
\text { Several times }=0.33 \\
\text { Often }=0\end{array}$ & $\begin{array}{l}4.7 \\
19.2 \\
39.1 \\
36.9\end{array}$ & $\begin{array}{l}3.06(1.68-5.57) \\
1.99(1.30-3.06) \\
1.40(0.94-2.08) \\
-\end{array}$ & 0.001 \\
\hline 45 & $\begin{array}{l}\text { Sleeps more than } \\
\text { regularly (trouble } \\
\text { getting out of bed, } \\
\text { falls asleep during } \\
\text { the day) }\end{array}$ & $\begin{array}{l}\text { SDZ, completed by } \\
\text { professional caregivers } \\
\text { Last three months }\end{array}$ & $\begin{array}{l}\text { Often }=1 \\
\text { Several times }=0.66 \\
\text { Sometimes }=0.33 \\
\text { Never/very rare }=0\end{array}$ & $\begin{array}{l}4.5 \\
9.8 \\
22.8 \\
62.9\end{array}$ & $\begin{array}{l}4.55(2.68-7.72) \\
2.85(1.84-4.42) \\
1.96(1.35-2.85) \\
-\end{array}$ & $<0.001$ \\
\hline 46 & Fast fatigued/listless & $\begin{array}{l}\text { SDZ, completed by } \\
\text { professional caregivers } \\
\text { Last three months }\end{array}$ & $\begin{array}{l}\text { Often }=1 \\
\text { Several times }=0.66 \\
\text { Sometimes }=0.33 \\
\text { Never/very rare }=0\end{array}$ & \begin{tabular}{l|}
6.4 \\
13.5 \\
35.3 \\
44.8
\end{tabular} & $\begin{array}{l}4.57(2.82-7.39) \\
2.03(1.28-3.21) \\
1.62(1.11-2.37) \\
-\end{array}$ & $<0.001$ \\
\hline 47 & $\begin{array}{l}\text { Is slow or passive in } \\
\text { his/her movements }\end{array}$ & $\begin{array}{l}\text { SDZ, completed by } \\
\text { professional caregivers } \\
\text { Last three months }\end{array}$ & $\begin{array}{l}\text { Never/very rare }=0 \\
\text { Sometimes }=0.33 \\
\text { Several times }=0.66 \\
\text { Often }=1\end{array}$ & $\begin{array}{l}6.5 \\
12.1 \\
26.5 \\
54.9\end{array}$ & $\begin{array}{l}4.66(2.89-7.50) \\
2.73(1.78-4.20) \\
1.64(1.11-2.42)\end{array}$ & $<0.001$ \\
\hline 48 & $\begin{array}{l}\text { Knowing which year } \\
\text { it is }\end{array}$ & $\begin{array}{l}\text { The Dementia } \\
\text { Questionnaire for } \\
\text { Mentally Retarded } \\
\text { Persons (DMR) }\end{array}$ & $\begin{array}{l}\text { Normally No }=1 \\
\text { Sometimes }=0.5 \\
\text { Normally Yes }=0\end{array}$ & $\begin{array}{l}57.4 \\
5.3 \\
37.2\end{array}$ & $\begin{array}{l}1.55(1.04-2.27) \\
1.18(0.57-2.45) \\
-\end{array}$ & 0.09 \\
\hline 49 & $\begin{array}{l}\text { Knowing the way to } \\
\text { familiar places }\end{array}$ & $\begin{array}{l}\text { The Dementia } \\
\text { Questionnaire for } \\
\text { Mentally Retarded } \\
\text { Persons (DMR) }\end{array}$ & $\begin{array}{l}\text { Normally No }=1 \\
\text { Sometimes }=0.5 \\
\text { Normally Yes }=0\end{array}$ & $\begin{array}{l}12.6 \\
7.6 \\
79.8\end{array}$ & $\begin{array}{l}3.43(2.36-5.00) \\
2.44(1.56-3.97) \\
-\end{array}$ & $<0.001$ \\
\hline
\end{tabular}


Table 4 continued

\begin{tabular}{|c|c|c|c|c|c|c|}
\hline$\#$ & Deficit & Additional information & Cut-off values and FI scores & $\begin{array}{l}\text { Percentage per } \\
\text { category }\end{array}$ & $\operatorname{HR}(95 \% \mathrm{CI})^{\mathrm{a}}$ & $p$ (for trend) \\
\hline 50 & Is seeing group mates & $\begin{array}{l}\text { The Dementia } \\
\text { Questionnaire for } \\
\text { Mentally Retarded } \\
\text { Persons (DMR) }\end{array}$ & $\begin{array}{l}\text { Normally No }=1 \\
\text { Sometimes }=0.5 \\
\text { Normally Yes }=0\end{array}$ & $\begin{array}{l}36.2 \\
36.5 \\
27.3\end{array}$ & $\begin{array}{l}2.50(1.59-3.91) \\
1.59(1.03-2.46) \\
-\end{array}$ & $<0.001$ \\
\hline 51 & $\begin{array}{l}\text { Knowing that today is } \\
\text { a weekend or a } \\
\text { week day }\end{array}$ & $\begin{array}{l}\text { The Dementia } \\
\text { Questionnaire for } \\
\text { Mentally Retarded } \\
\text { Persons (DMR) }\end{array}$ & $\begin{array}{l}\text { Normally No }=1 \\
\text { Sometimes }=0.5 \\
\text { Normally Yes }=0\end{array}$ & $\begin{array}{l}23.5 \\
9.7 \\
66.8\end{array}$ & $\begin{array}{l}3.56(2.46-5.16) \\
2.06(1.28-3.30) \\
-\end{array}$ & $<0.001$ \\
\hline
\end{tabular}

${ }^{a} H R$ Hazard ratio, calculated for each provided category using the 'healthiest' option as a reference group; HR are adjusted for age, gender, level of ID, and the presence of Down syndrome

Table 5 Frailty phenotype variables as originally intended by Fried et al. $(2001,2012)$ and the adapted frailty phenotype by Evenhuis et al. (2012)

\begin{tabular}{|c|c|c|}
\hline & Original measurement & Applied to the HA-ID study \\
\hline Weakness & $\begin{array}{l}\text { Grip strength: lowest } 20 \% \text { (by } \\
\text { gender, body mass index) }\end{array}$ & $\begin{array}{l}\text { As originally suggested using the Jamar Hand Dynamometer [\#5030J1, Sammons } \\
\text { Preston Rolyan, Dolgeville, NY] }\end{array}$ \\
\hline $\begin{array}{l}\text { Shrinking: } \\
\text { Weight loss }\end{array}$ & $\begin{array}{l}>10 \mathrm{lbs}(4.54 \mathrm{~kg}) \text { lost } \\
\text { unintentionally in prior year }\end{array}$ & $\begin{array}{l}\text { An item of the Mini Nutritional Assessment, } \\
\text { weight loss during the past } 3 \text { months was assessed on a } \\
\text { 4-point rating scale. Losses }>3 \mathrm{~kg} \text { were scored }\end{array}$ \\
\hline Exhaustion & Exhaustion by self-report & $\begin{array}{l}\text { Exhaustion was estimated using the } \\
\text { item "Lacks energy" of the Anxiety, Depression and } \\
\text { Mood Scale, using a 4-point rating scale. No exhaustion was classified as no problems or } \\
\text { mild problems and exhaustion was classified as moderate problem and severe problem. } \\
\text { Because self-report is difficult for a large part of the intellectual disabled population, } \\
\text { proxy-based answers were used }\end{array}$ \\
\hline Slowness & $\begin{array}{l}\text { Walking time } / 15 \mathrm{ft} \text { : slowest } 20 \% \\
\text { (by gender, height) }\end{array}$ & $\begin{array}{l}\text { As originally suggested. In addition, all participants in a wheelchair and all participants } \\
\text { who could not engage in the walking speed assessment because of physical limitations } \\
\text { were classified as 'slow' }\end{array}$ \\
\hline Low activity & $\begin{array}{l}\mathrm{kcal} / \text { week: lowest } 20 \% \\
\text { males: }<383 \mathrm{kcal} / \text { week } \\
\text { females: }<270 \mathrm{kcal} / \text { week }\end{array}$ & $\begin{array}{l}\text { All participants walking fewer than } 5000 \text { steps/day (sedentary lifestyle) were scored as } \\
\text { 'low activity,' as were all participants in a wheelchair and all participants who could } \\
\text { not engage in the walking speed assessment because of physical limitations }\end{array}$ \\
\hline
\end{tabular}




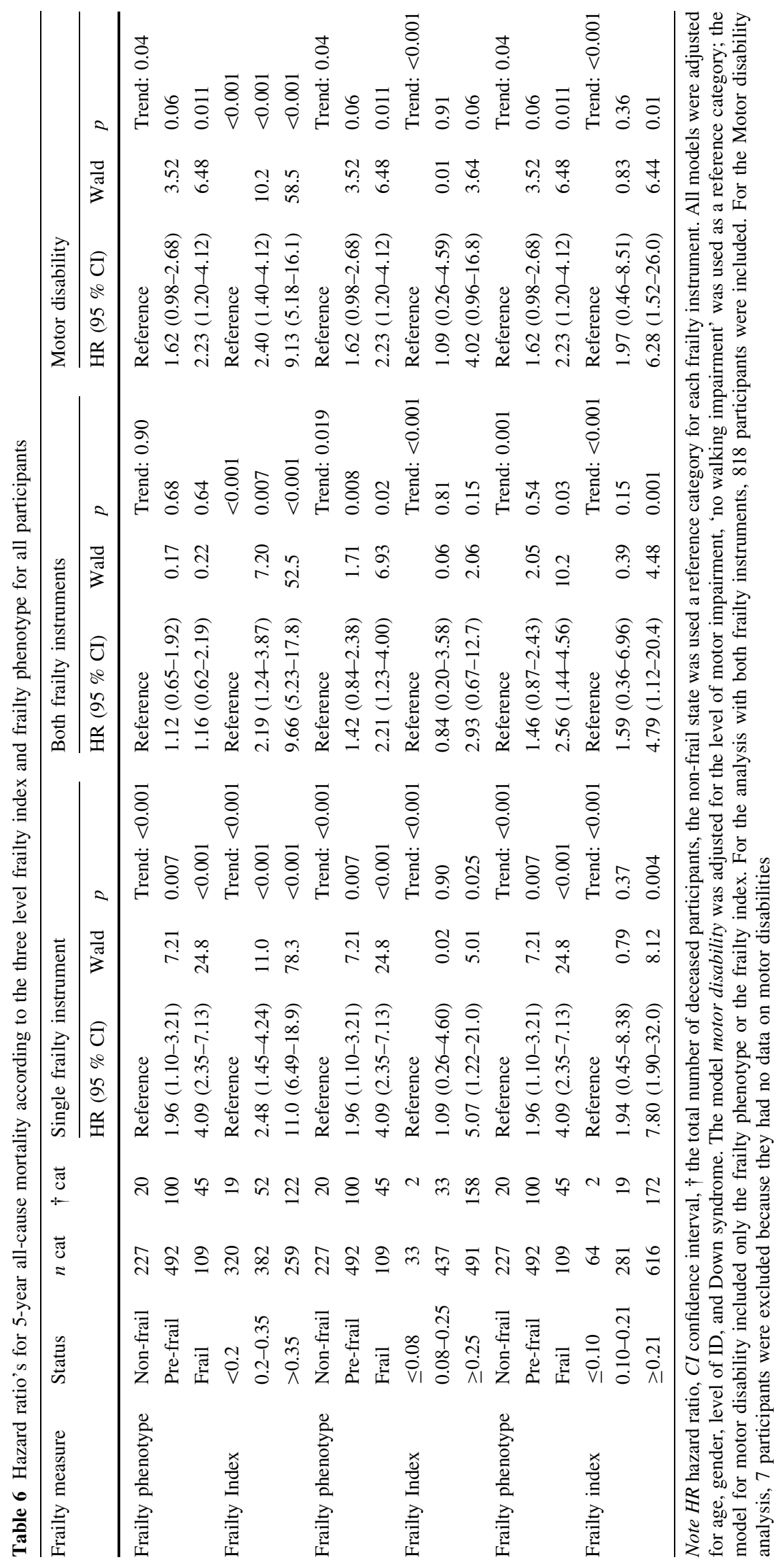


Table 7 Forward Cox proportional Hazard model using all available frailty variables as independent predictors for survival

\begin{tabular}{lccccc}
\hline Frailty item & Wald & $p$ value & HR & Lower CI & Upper CI \\
\hline Walking stairs & 20.2 & $<0.001$ & 2.39 & 1.63 & 3.49 \\
Present at day care center & 22.0 & $<0.001$ & 2.17 & 1.57 & 3.00 \\
Panic attacks & 4.30 & $<0.001$ & 1.66 & 1.03 & 2.67 \\
Weight loss & 9.50 & 0.002 & 2.09 & 1.31 & 3.33 \\
Cardiovascular & 19.8 & $<0.001$ & 2.27 & 1.58 & 3.25 \\
Asthma/COPD & 12.2 & $<0.001$ & 1.86 & 1.31 & 2.62 \\
Visual/hearing impairments & 8.88 & 0.003 & 1.74 & 1.21 & 2.50 \\
hemoglobin & 16.7 & $<0.001$ & 1.89 & 1.39 & 2.56 \\
Sleeps more than regularly & 15.3 & $<0.001$ & 2.69 & 1.64 & 4.42 \\
Slow or passive & 15.4 & $<0.001$ & 2.70 & 1.64 & 4.42 \\
Knowing week day or weekend day & 19.2 & $<0.001$ & 2.08 & 1.50 & 2.88 \\
Hospitalization & 4.96 & 0.026 & 2.13 & 1.10 & 4.14 \\
Fast fatigue & 5.87 & 0.015 & 0.47 & 0.26 & 0.87 \\
\hline
\end{tabular}

\section{References}

Blodgett J, Theou O, Kirkland S, Andreou P, Rockwood K (2015) Frailty in NHANES: comparing the frailty index and phenotype. Arch Gerontol Geriatr 60:464-470. doi:10.1016/j.archger.2015. 01.016

Bouillon K, Kivimaki M, Hamer M, Sabia S, Fransson EI, SinghManoux A, Gale CR, Batty GD (2013) Measures of frailty in population-based studies: an overview. BMC Geriatr 13:64. doi:10.1186/1471-2318-13-64

Brehmer-Rinderer B, Zeilinger EL, Radaljevic A, Weber G (2013) The Vienna frailty questionnaire for persons with intellectual disabilities - revised. Res Dev Disabil 34:1958-1965. doi:10. 1016/j.ridd.2013.03.004

Cesari M, Gambassi G, van Kan GA, Vellas B (2014) The frailty phenotype and the frailty index: different instruments for different purposes. Age Ageing 43:10-12. doi:10.1093/ageing/ aft160

Clegg A, Young J, Iliffe S, Olde Rikkert MG, Rockwood K (2013) Frailty in elderly people. Lancet 381:752-762. doi:10.1016/ S0140-6736(12)62167-9

Cohen J (1960) A coefficient of agreement for nominal scales. Educ Phychol Meas 20:37-46

Collerton J, Martin-Ruiz C, Davies K, Hilkens CM, Isaacs J, Kolenda C, Parker C, Dunn M, Catt M, Jagger C, von Zglinicki T, Kirkwood TB (2012) Frailty and the role of inflammation, immunosenescence and cellular ageing in the very old: crosssectional findings from the Newcastle 85+ Study. Mech Ageing Dev 133:456-466. doi:10.1016/j.mad.2012.05.005

de la Rica-Escuin M, Gonzalez-Vaca J, Varela-Perez R, ArjonillaGarcia MD, Silva-Iglesias M, Oliver-Carbonell JL, Abizanda P (2014) Frailty and mortality or incident disability in institutionalized older adults: the FINAL Study. Maturitas. doi:10.1016/j. maturitas.2014.05.022

de Vries NM, Staal JB, van Ravensberg CD, Hobbelen JS, Olde Rikkert MG, Nijhuis-van der Sanden MW (2011) Outcome instruments to measure frailty: a systematic review. Ageing Res Rev 10:104-114. doi:10.1016/j.arr.2010.09.001

Esbensen AJ, Rojahn J, Aman MG, Ruedrich S (2003) Reliability and validity of an assessment instrument for anxiety, depression, and mood among individuals with mental retardation. J Autism Dev Disord 33:617-629

Evenhuis HM, Hermans H, Hilgenkamp TI, Bastiaanse LP, Echteld MA (2012) Frailty and disability in older adults with intellectual disabilities: results from the healthy ageing and intellectual disability study. J Am Geriatr Soc 60:934-938. doi:10.1111/j. 1532-5415.2012.03925.x

Evenhuis HM, Schoufour JD, Echteld MA (2013) Frailty and intellectual disability: a different operationalization? Dev Disabil Res Rev 18:17-21. doi:10.1002/ddrr.1124

Feeny D, Huguet N, McFarland BH, Kaplan MS, Orpana H, Eckstrom E (2012) Hearing, mobility, and pain predict mortality: a longitudinal population-based study. J Clin Epidemiol 65:764-777. doi:10.1016/j.jclinepi.2012.01.003

Fried LP, Tangen CM, Walston J, Newman AB, Hirsch C, Gottdiener J, Seeman T, Tracy R, Kop WJ, Burke G, McBurnie MA, Cardiovascular Health Study Collaborative Research Group (2001) Frailty in older adults: evidence for a phenotype. J Gerontol A Biol Sci Med Sci 56:M146-M156

Fried LP, Ferrucci L, Darer J, Williamson JD, Anderson G (2004) Untangling the concepts of disability, frailty, and comorbidity: implications for improved targeting and care. J Gerontol A Biol Sci Med Sci 59:255-263

Gobbens RJ, van Assen MA, Luijkx KG, Wijnen-Sponselee MT, Schols JM (2010) Determinants of frailty. J Am Med Dir Assoc 11:356-364. doi:10.1016/j.jamda.2009.11.008

Heagerty JP, Lumley T, Pepe MS (2000) Time-Dependent ROC curves for censored survival data and a diagnostic marker. Biometrics 56:337-344

Hilgenkamp TI, Bastiaanse LP, Hermans H, Penning C, van Wijck R, Evenhuis HM (2011) Study healthy ageing and intellectual disabilities: recruitment and design. Res Dev Disabil 32:1097-1106. doi:10.1016/j.ridd.2011.01.018

Hilgenkamp TI, Reis D, van Wijck R, Evenhuis HM (2012) Physical activity levels in older adults with intellectual disabilities are extremely low. Res Dev Disabil 33:477-483. doi:10.1016/j.ridd. 2011.01.018

Hogan DB, Freiheit EA, Strain LA, Patten SB, Schmaltz HN, Rolfson D, Maxwell CJ (2012) Comparing frailty measures in their ability to predict adverse outcome among older residents of assisted living. BMC Geriatr 12:56. doi:10.1186/1471-2318-1256

Hoogendijk EO, van Kan GA, Guyonnet S, Vellas B, Cesari M (2015) Components of the Frailty Phenotype in Relation to the Frailty Index: results From the Toulouse Frailty Platform. J Am Med Dir Assoc 16:855-859. doi:10.1016/j.jamda.2015.04.007

Hoover M, Rotermann M, Sanmartin C, Bernier J (2013) Validation of an index to estimate the prevalence of frailty among community-dwelling seniors. Health Rep 24:10-17 
Kulminski AM, Ukraintseva SV, Kulminskaya IV, Arbeev KG, Land K, Yashin AI (2008) Cumulative deficits better characterize susceptibility to death in elderly people than phenotypic frailty: lessons from the Cardiovascular Health Study. J Am Geriatr Soc 56:898-903. doi:10.1111/j.1532-5415.2008.01656.x

Liu CK, Fielding RA (2011) Exercise as an intervention for frailty. Clin Geriatr Med 27:101-110. doi:10.1016/j.cger.2010.08.001

Majer IM, Nusselder WJ, Mackenbach JP, Klijs B, van Baal PH (2011) Mortality risk associated with disability: a populationbased record linkage study. Am J Public Health 101:e9-15. doi:10.2105/AJPH.2011.300361

Mitnitski A, Mogilner AJ, Rockwood K (2001) Accumulation of deficits as a proxy measure of aging. ScientificWorldJournal 1:323-336. doi:10.1100/tsw.2001.58

Mitnitski A, Song X, Rockwood K (2012) Trajectories of changes over twelve years in the health status of Canadians from late middle age. Exp Gerontol 47:893-899. doi:10.1016/j.exger. 2012.06.015

Mitnitski A, Song X, Rockwood K (2013) Assessing biological aging: the origin of deficit accumulation. Biogerontology 14:709-717. doi:10.1007/s10522-013-9446-3

Oppewal A, Hilgenkamp TI, van Wijck R, Schoufour JD, Evenhuis HM (2014) Physical fitness is predictive for a decline in daily functioning in older adults with intellectual disabilities: results of the HA-ID study. Res Dev Disabil 35:2299-2315. doi:10.1016/j. ridd.2014.05.027

Ravindrarajah R, Lee DM, Pye SR, Gielen E, Boonen S, Vanderschueren D, Pendleton N, Finn JD, Tajar A, O'Connell MD, Rockwood K, Bartfai G, Casanueva FF, Forti G, Giwercman A, Han TS, Huhtaniemi IT, Kula K, Lean ME, Punab M, Wu FC, O'Neill TW, European Male Aging Study Group (2013) The ability of three different models of frailty to predict all-cause mortality: results from the European Male Aging Study (EMAS). Arch Gerontol Geriatr 57:360-368. doi:10.1016/j.archger.2013. 06.010

Rockwood K, Mitnitski A (2007) Frailty in relation to the accumulation of deficits. J Gerontol A Biol Sci Med Sci 62:722-727

Rockwood K, Howlett SE, MacKnight C, Beattie BL, Bergman H, Hebert R, Hogan DB, Wolfson C, McDowell I (2004) Prevalence, attributes, and outcomes of fitness and frailty in community-dwelling older adults: report from the Canadian study of health and aging. J Gerontol A Biol Sci Med Sci 59:1310-1317

Rockwood K, Mitnitski A, Song X, Steen B, Skoog I (2006) Longterm risks of death and institutionalization of elderly people in relation to deficit accumulation at age 70 . J Am Geriatr Soc 54:975-979. doi:10.1111/j.1532-5415.2006.00738.x

Rockwood K, Andrew M, Mitnitski A (2007) A comparison of two approaches to measuring frailty in elderly people. J Gerontol A Biol Sci Med Sci 62:738-743

Rockwood K, Song X, Mitnitski A (2011) Changes in relative fitness and frailty across the adult lifespan: evidence from the canadian national population health survey. Can Med Assoc J 183:E487E494. doi: 10.1503/cmaj.101271

Schoufour JD, Mitnitski A, Rockwood K, Evenhuis HM, Echteld MA (2013) Development of a frailty index for older people with intellectual disabilities: results from the HA-ID study. Res Dev Disabil 34:1541-1555. doi:10.1016/j.ridd.2013.01.029

Schoufour JD, Mitnitski A, Rockwood K, Hilgenkamp TI, Evenhuis HM, Echteld MA (2014) Predicting disabilities in daily functioning in older people with intellectual disabilities using a frailty index. Res Dev Disabil 35:2267-2277. doi:10.1016/j.ridd. 2014.05.022

Schoufour JD, Echteld MA, Bastiaanse LP, Evenhuis HM (2015) The use of a frailty index to predict adverse health outcomes (falls, fractures, hospitalization, medication use, comorbid conditions) in people with intellectual disabilities. Res Dev Disabil 38:39-47. doi:10.1016/j.ridd.2014.12.001

Searle SD, Mitnitski A, Gahbauer EA, Gill TM, Rockwood K (2008) A standard procedure for creating a frailty index. BMC Geriatr 8:24. doi:10.1186/1471-2318-8-24

Song X, Mitnitski A, Rockwood K (2010) Prevalence and 10-year outcomes of frailty in older adults in relation to deficit accumulation. J Am Geriatr Soc 58:681-687. doi:10.1111/j. 1532-5415.2010.02764.x

Theou O, Rockwood K (2015) Comparison and Clinical Applications of the Frailty Phenotype and Frailty Index Approaches. Interdiscip Top Gerontol Geriatr 41:74-84. doi:10.1159/000381166

Theou O, Stathokostas L, Roland KP, Jakobi JM, Patterson C, Vandervoort AA, Jones GR (2011) The effectiveness of exercise interventions for the management of frailty: a systematic review. Journal of Aging Research 2011:569194. doi:10.4061/2011/ 569194

Theou O, Rockwood MR, Mitnitski A, Rockwood K (2012) Disability and co-morbidity in relation to frailty: how much do they overlap? Arch Gerontol Geriatr 55:e1-e8. doi:10.1016/j.archger. 2012.03.001

Theou O, Cann L, Blodgett J, Wallace LM, Brothers TD, Rockwood $\mathrm{K}$ (2015) Modifications to the frailty phenotype criteria: systematic review of the current literature and investigation of 262 frailty phenotypes in the Survey of Health, Ageing, and Retirement in Europe. Ageing Res Rev 21:78-94. doi:10.1016/j. arr.2015.04.001

Woo J, Leung J, Morley JE (2012) Comparison of frailty indicators based on clinical phenotype and the multiple deficit approach in predicting mortality and physical limitation. J Am Geriatr Soc 60:1478-1486. doi:10.1111/j.1532-5415.2012.04074.x

van Schijndel-Speet M, Meijer MLM, Evenhuis HM, Wijck van R, Echteld MA (submitted) Applicable and valid measurements of physical activity among people with intellectual disabilities and a low walking speed 